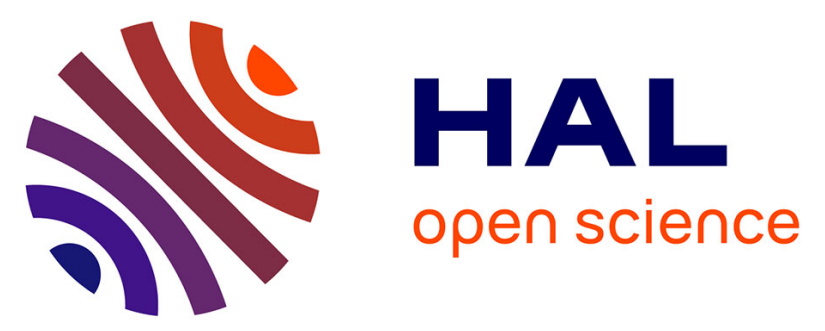

\title{
Female-biased sex ratios unrelated to Wolbachia infection in European species of the Jaera albifrons complex (marine isopods)
}

Ambre Ribardière, Julia Centanni, Arnaud Dano, Jérôme Coudret, Claire Daguin-Thiébaut, Céline Houbin, Elise Kerdoncuff, Ségolène Jambut, Richard Cordaux, Thomas Broquet

\section{To cite this version:}

Ambre Ribardière, Julia Centanni, Arnaud Dano, Jérôme Coudret, Claire Daguin-Thiébaut, et al.. Female-biased sex ratios unrelated to Wolbachia infection in European species of the Jaera albifrons complex (marine isopods). Journal of Experimental Marine Biology and Ecology, 2018, 509, pp.91-98. 10.1016/j.jembe.2018.09.002 . hal-02006763

\section{HAL Id: hal-02006763 https://hal.sorbonne-universite.fr/hal-02006763}

Submitted on 4 Feb 2019

HAL is a multi-disciplinary open access archive for the deposit and dissemination of scientific research documents, whether they are published or not. The documents may come from teaching and research institutions in France or abroad, or from public or private research centers.
L'archive ouverte pluridisciplinaire HAL, est destinée au dépôt et à la diffusion de documents scientifiques de niveau recherche, publiés ou non, émanant des établissements d'enseignement et de recherche français ou étrangers, des laboratoires publics ou privés. 
1 Female-biased sex ratios unrelated to Wolbachia infection in European species of the Jaera albifrons

2 complex (marine isopods)

3

4

5 Ambre Ribardière ${ }^{1}$, Julia Centanni ${ }^{1}$, Arnaud Dano ${ }^{1}$, Jérôme Coudret ${ }^{1}$, Claire Daguin-Thiebaut ${ }^{1}$, Céline 6 Houbin $^{2}$, Elise Kerdoncuff ${ }^{1}$, Ségolène Jambut ${ }^{1}$, Richard Cordaux ${ }^{3}$, Thomas Broquet $^{1}$

7

8

9 1- CNRS \& Sorbonne Université, UMR 7144, Station Biologique de Roscoff, 29680 Roscoff, France.

2- CNRS \& Sorbonne Université, FR2424, Station Biologique de Roscoff, 29680 Roscoff, France.

3- Laboratoire Ecologie et Biologie des Interactions, Université de Poitiers, UMR CNRS 7267, 86000 


\section{Abstract}

Female-biased sex ratios and reproductive isolation in arthropods can be caused by endosymbiotic Wolbachia bacteria that manipulate the reproductive system of their host. Wolbachia is particularly common in terrestrial host species, but its frequency in marine arthropods is less well known. Here we asked whether Wolbachia bacteria are accountable for the female-biased sex ratio and variation in reproductive isolation levels observed in the four European species of the Jaera albifrons complex (marine intertidal isopods). We analysed the sex ratio in young adults reared in the laboratory (indicative of the sex ratio at birth), compared it with the adult sex ratio in natural populations, and performed a molecular survey of Wolbachia infection based upon amplification of three gene targets using 11 different protocols tested in 817 individuals from all species of the Jaera albifrons complex. One species (J. ischiosetosa) had a female-biased sex ratio at birth but showed no sign of infection by Wolbachia bacteria. This species, together with two others (J. albifrons and J. forsmani) also displayed female-biased sex ratio in adults in nature, while the adult sex ratio in the fourth European species (J. praehirsuta) was unbiased. A new Wolbachia strain was identified in J. albifrons and J. praehirsuta, albeit at very low frequency in populations. We conclude that Wolbachia bacteria are present in at least two species of the Jaera albifrons complex, but their prevalence is too low to have any effect on sex ratio and reproductive isolation. A sex ratio distorter other than Wolbachia may be acting in some J. ischiosetosa populations, and we hypothesize that the adult female excess seen in most species results from habitat-dependent, male-biased mortality in natural conditions.

Keywords: female biased sex ratio, Wolbachia endosymbionts, marine crustaceans, Jaera albifrons 


\section{Introduction}

Sex allocation theory predicts that frequency-dependent selection favours equal investments into male and female offspring (Fisher, 1999). If production costs are equivalent between offspring of the two sexes then the number of males and the number of females in a population are expected to be balanced. However, there are many constraints to the regulation of this equilibrium (West and Sheldon, 2002), and biased sex ratios are common in nature (Hardy, 2002). Causes of departure from Fisher's null model include in particular local mate competition between individuals for access to sexual partners (e.g. Werren, 1983), meiotic drive on sex chromosomes (reviewed in Jaenike, 2001) and cytoplasmic sex ratio distorters (Cordaux et al., 2011; Taylor, 1990) such as Wolbachia. Wolbachia is a group of cytoplasmic endosymbiotic bacteria found in a large number of invertebrates (Werren et al., 2008). It is predominantly transmitted via female gametes (Werren et al., 2008) and it often promotes its transmission by interfering in the process of reproduction of its host (Rousset et al., 1992; Werren, 1997). Wolbachia is notably known to be involved in the conversion of genetic males into functional phenotypic neo-females, a process called feminization (Bouchon et al., 2008; Cordaux and Gilbert, 2017; Rigaud et al., 1999; Werren et al., 2008). It can also induce parthenogenesis in several otherwise sexually reproducing species, or specifically kill the male offspring of infected females (Hurst et al., 1999). Therefore, in absence of compensatory mechanisms (which would be readily favoured by sex ratio selection), Wolbachia can cause an increase in the proportion of females in infected populations.

In addition, these bacteria can also play a role in speciation by inducing interspecific cytoplasmic incompatibilities (Rousset et al., 1992; Telschow et al., 2007; Werren, 1997; Werren et al., 2008). For example, studies on wasps of the genus Nasonia (Bordenstein et al., 2001; Bordenstein and Werren, 1998; Bordenstein and Werren, 2007) have shown that Wolbachia can cause reproductive isolation between two closely related species by bidirectional incompatibility of two strain types. Furthermore, Wolbachia can also drive the reinforcement of behavioural isolation between infected and uninfected species (Jaenike et al., 2006). 
Although Wolbachia is essentially maternally transmitted, its capacity to move into new hosts via horizontal transmission has promoted its spread to different invertebrate clades (Cordaux et al., 2001; Duron and Hurst, 2013; Turelli et al., 2018; Vavre et al., 1999). Wolbachia is particularly frequent in arthropods, infecting mites (Breeuwer and Jacobs, 1996), crustaceans (Bouchon et al., 1998) and insects (Werren and Windsor, 2000). Although the prevalence of Wolbachia is difficult to quantify, it was estimated to infect 20 to $60 \%$ of insects (Sazama et al., 2017; Werren and Windsor, 2000). Few species of marine crustaceans are known to be infected: Wolbachia was found in a handful of marine amphipods, isopods, and cirripedes (Bouchon et al., 1998; Cordaux et al., 2012). In this study, we are interested in the Jaera albifrons complex, a group of small (2-5 mm) marine isopods where there are both (i) observations of strongly female-biased sex ratios and (ii) variations in the level of reproductive isolation between species. The Jaera albifrons complex includes five intertidal species that live on the shores of the temperate and cold waters of the NorthAtlantic Ocean (Bocquet, 1953; Bocquet, 1972; Naylor and Haahtela, 1966). Three of these species (J. albifrons, J. praehirsuta, and J. ischiosetosa) have an amphi-atlantic distribution, while the other two species are restricted either to the North-American East coast (J. posthirsuta) or the European coasts (J. forsmani).

Nearly all demographic analyses of the four species that are found on the European coasts have reported female-biased sex ratios in adults in natural populations (Cléret, 1966b; Jaźdźewski, 1969; Jones and Naylor, 1971; Naylor and Haahtela, 1967; Naylor et al., 1961; Piertney and Carvalho, 1996; Solignac, 1976) with male proportions locally as low as 0.07 (J. ischiosetosa in the UK, Jones and Naylor, 1971). To our knowledge no such estimations have been reported for J. posthirsuta. Two studies examined the sex ratio in offspring reared in the laboratory (with low mortality, sex ratio at maturity is informative of sex-ratio at birth). In contradiction with the results from adults in natural populations, these two studies found unbiased offspring sex ratio in species J. albifrons (Cléret, 1966b; Piertney and Carvalho, 1996), J. forsmani, and J. ischiosetosa (Cléret, 1966b). Solignac (1978, p. 89) also reported that he did not observe a biased sex ratio in young adults reared in the 
laboratory. However, the figures reported by this author suggest a slight excess of females at birth in J. ischiosetosa ( $r=0.42$, binomial test $p=0.02$, from table 4.1 in Solignac 1978: 89). In addition, a notable exception concerns a population from Normandy, France, where a subset of J. praehirsuta females were shown to produce an excess of female offspring (Cléret, 1966a). The author concluded that a genetic factor lethal for the males was segregating in this population.

Observations of even numbers of males and females at birth are compatible with the genetic sex-determination system that was identified for the four European species (males ZZ, females ZW1W2, Staiger and Bocquet, 1954; Staiger and Bocquet, 1956, again to our knowledge this system has not yet been confirmed in J. posthirsuta). Accordingly, all four European species of the Jaera albifrons group have long been proven to be strictly gonochoric (no sex-change, which is a strategy found in some other isopods, as reviewed in Policansky, 1982; Poore and Bruce, 2012). Moreover, genetic sex determination has been confirmed through repeated karyotype studies (Lécher, 1967; Lécher and Prunus, 1971) and molecular linkage maps (AFLP: Mifsud, 2011, and RAD-seq genotyping: Ribardière et al. unpublished). One study also found sex determination in species J. albifrons to be unaffected by strong variations in temperature conditions (Piertney and Carvalho, 1996). Several ideas have been put forward to explain why adult females are systematically more abundant than adult males in natural populations. First, males are smaller and less conspicuous than females, meaning that they could simply be missed during collection in the field (Cléret, 1966b). However, sex ratio investigations based on a careful dedicated sampling consistently found female biases (Jaźdźewski, 1969; Naylor et al., 1961; Piertney and Carvalho, 1996). Second, it has been suggested that males have a shorter lifespan than females (Jaźdźewski, 1969; Solignac, 1976; Steele and Steele, 1972), although the only data available, obtained in laboratory conditions, suggest otherwise (Solignac, 1976, J. albifrons and J. ischiosetosa males both had better survival than females). Finally, strong sex ratio biases could be driven by sex ratio distorters such as mitochondrial variants or cytoplasmic microorganisms (reviewed in Duron et al., 2008; Duron and Hurst, 2013; Jaenike, 2001; Werren et al., 2008). In isopods in particular, Wolbachia is the most frequent inherited 
bacterium that can manipulate reproduction of its host. Yet an effect of sex ratio distorters would be visible not only at the adult stage in natural populations but also in young adults reared in the laboratory. Such effects have not yet been observed (Cléret, 1966b; Piertney and Carvalho, 1996) except in some specific populations of J. praehirsuta (Cléret, 1966a) and perhaps J. ischiosetosa (Solignac, 1978).

In summary, sex ratio biases in the Jaera albifrons complex are intriguing, and the causes of female excesses in adults and perhaps in some cases in offspring are unresolved. In addition to sex ratio biases, another reason to investigate whether Wolbachia endosymbionts are present in the Jaera albifrons complex is that they could play a role in reproductive isolation. Species in this complex are isolated by a combination of ecological isolation, sexual isolation, and genetic incompatibilities (reviewed in Mifsud, 2011; Ribardière et al., 2017; Solignac, 1981) so that they generally coexist without hybridization. But in some instances, local populations undergo hybridization (Solignac, 1969a, b; Solignac, 1978). Species J. albifrons and J. praehirsuta are particularly interesting in this respect as replicate mixed populations show varying degrees of introgressive hybridization (Ribardière, 2017; Ribardière et al., 2017). It would be important to know if Wolbachia may play any role in this variation. Interestingly, the J. praehirsuta broods showing aberrant sex ratios as observed by Cléret (1966a) came from a population with introgressive hybridization between J. praehirsuta and J. albifrons (Solignac 1969a, Ribardière et al. 2017). Bouchon et al. (1998) found no Wolbachia in J. albifrons, but it could have been due to sampling insufficiency (three individuals were tested). Recently, Wenzel et al. (2018) performed an analysis of the microbiome of the four European species of the Jaera albifrons complex using bacterial 16S rDNA sequencing in populations from Scotland. None of the bacterial 16S sequences that they identified belonged to the Wolbachia group. Here we had two objectives. Our first objective was to compare sex ratios at birth vs adult stage in the four European species of the Jaera albifrons complex. For that, we reanalysed data from a large number of broods reared in the laboratory as part of an ongoing project on speciation in the Jaera albifrons complex (Ribardière et 
al., 2017). Although adult sex ratios have been well documented by others, for comparison with our brood data we also estimated sex ratios in natural populations using a dedicated sampling effort in the region where most of our brood data came from. Our second objective was to screen all five species of the complex with a targeted assay for the presence of Wolbachia endosymbionts using several gene targets and populations of various geographic origins. We focused particularly on the $J$. albifrons / J. praehirsuta pair in regions with varying degrees of reproductive isolation. With this, our overarching goal was to test whether Wolbachia may or may not be involved in sex ratio biases and reproductive isolation in the Jaera albifrons complex.

\section{Methods}

\subsection{Study system and general strategy}

The five species of the Jaera albifrons group are found mid- to upper-shore, where they can locally show some differential preferences in substrate (under pebbles or on seaweeds), position in the intertidal zone, salinity, and exposure (Bocquet, 1953; Jones, 1972; Naylor and Haahtela, 1966). Individuals from the different species have the same general morphology, with males (2-3 $\mathrm{mm})$ smaller than females $(5 \mathrm{~mm})$. Males from the five species differ only in the number and position of spines and setae that they use to court females (Bocquet, 1953), and females cannot be distinguished based on morphology. Development is direct, there is no pelagic larval stage, and offspring measure ca. $0.5 \mathrm{~mm}$ when they are released. Individuals become sexually mature within 4 to 5 weeks and can then be sexed based on praeoperculum differentiation (e.g. Solignac, 1979). We define sex ratio $(r)$ as the proportion of males in a sample.

Our sex ratio analyses are based on two classes of data. First, we determined the sex of adult individuals sampled in natural populations. These analyses, based on a small number of sampling sites, were used to check if our study populations conform to the well-described sex ratio biases reported in the literature. Second, we used a much larger dataset to analyse sex ratios in broods reared in the laboratory. When survival in the laboratory is high (see results and discussion), then the 
173

sex ratio measured at least five weeks after birth is a good proxy for the sex ratio at birth, which has been less well documented than adult sex ratios and brings complementary information. In addition to sex ratio analyses we used a multi-target molecular approach to search for Wolbachia in a large number of individuals from different species and geographic origins.

\subsection{Adult sex ratio in natural populations}

Because males of all four European species of the Jaera albifrons group are smaller than females and can thus be more easily missed during field sampling, we selected four sampling sites/habitats (Table 1) where we carefully sampled all individuals in a delimited area. In our primary study region (Brittany, western France), species J. albifrons, J. ischiosetosa, and J. forsmani live under rocks, while J. praehirsuta is found mainly on Fucus vesiculosus and Ascophyllum nodosum seaweeds (Bocquet 1953, Ribardière et al. 2017). To estimate sex ratio we thus sampled all individuals found on a limited number of rocks or algae in each site (5-15 pebbles or stones of different sizes or a random sample of algae typically contained within $10 \mathrm{~m}^{2}$, depending on local density). All individuals were brought back to the laboratory where they were sexed and males were identified based on their secondary sexual characters. The four sampling site/habitat combinations were previously known to shelter a single species, meaning that there would be little risk that the females (for which species cannot be identified from morphological characters) could belong to two different species (see results). Binomial tests were used to test for a departure from even sex ratio (all analyses performed in R, R Core Team, 2016).

\subsection{Sex ratio in broods reared in the laboratory.}

Raising individuals from birth to sexual maturity in the laboratory gives access to sex ratio under controlled conditions, and, if survival has been high enough (see results), to estimate sex ratio at birth. In the course of an ongoing project on the Jaera albifrons complex we raised a large number of broods in standardized laboratory conditions. These data were used to count the number of males 
and females in each brood and compare sex ratio estimates across broods and populations. Rearing conditions are detailed in supplementary material.

All broods were produced by females maintained in the laboratory, but within two different experimental frameworks. First, we reared broods produced by females that came directly from the field. This is possible because females store sperm and can thus produce offspring in the laboratory in absence of males (each female was kept in an separate well and was thus never in contact with males). Within this framework, we have no information on the father of the offspring, the age of the mother, and little a priori information, if any, on the female's species (this was later determined from the morphological characters borne by male offspring of each female).

Second, we reared broods produced through controlled experimental crosses featuring parents that had been reared in captivity. In that case both the mother and father of each brood are known and identified, and the parents were virgin before the experiment (i.e. in most cases we analysed their first brood, or we knew how many broods were produced before). Such controlled crosses were run only with J. albifrons and J. praehirsuta. Since we did not detect any significant difference in sex ratio between the broods produced by females caught in the wild vs those from controlled experimental crosses (supplementary material Figure S1), we did not separate these two types of data for sex ratio analyses (unless stated otherwise).

Overall, we used data from 375 broods reared in the laboratory between 2013 and 2016. A large fraction of the data came from a region of France where we have been studying natural hybridization between J. albifrons and J. praehirsuta (region Normandy, Ribardière et al., 2017). These data (243 broods) were analysed separately (next section). The other fraction corresponds to 132 broods from four species that were originally sampled in region Brittany, where no hybridization has been detected (Ribardière et al., 2017): J. albifrons ( $n=72$ broods), J. praehirsuta $(n=25)$, J. ischiosetosa $(n=12)$, and J. forsmani $(n=23)$. We used these data to estimate brood sex ratio and compare it with adult sex ratio estimated in natural populations from Brittany (as described above). 
Sex ratio in case of introgressive hybridization between J. albifrons and J. praehirsuta

Two analyses were performed to investigate the consequences of introgressive hybridization on sex ratio in J. albifrons and J. praehirsuta. First, we compared the sex ratio in broods from each species in regions Brittany (no hybridization) vs Normandy (hybridization). For that we used broods from females sampled in the wild (J. albifrons in Brittany, $n=34$ broods, Normandy, $n=22 ; \mathrm{J}$. praehirsuta in Brittany, $n=15$, Normandy, $n=39$ ). Second, we compared the sex ratio in broods resulting from controlled intra- and inter-specific crosses. For that we used intra-specific J. albifrons crosses ( $n=131$ broods), intra-specific J. praehirsuta crosses $(n=134)$, first-generation hybrids $(n=$ 17), and backcrosses (F1 hybrid females crossed with either J. albifrons or J. praehirsuta males, $n=$ 58). Generalized linear models with a logit link function and binomial errors were used to test for differences in sex ratio amongst categories.

\subsection{PCR detection of Wolbachia}

The presence of Wolbachia endosymbionts can be detected by PCR amplification using host DNA extracts (potentially containing co-extracted DNA from endosymbionts) with Wolbachia specific primers (Simoes et al., 2011).

A total of 817 individuals belonging to the five species of the Jaera albifrons complex, including 321 females and 496 males, were tested. We used samples from 9 populations from France, 2 populations from Quebec (Canada), 1 population from the Isles of Scilly (United-Kingdom), and 1 population from Troms $\varnothing$ (Norway), as detailed in supplementary Table S1. The samples from France included J. albifrons and J. praehirsuta from sites with and without hybridization, as described above for the sex ratio analyses. In addition, because the presence of Wolbachia has been investigated in few marine species, we also analysed 34 individuals of 6 marine isopod and amphipod species (Table S2).

Total DNA (from Jaera spp. and potential Wolbachia sp.) was extracted using either a NucleoSpin Tissue kit (Macherey-Nagel) or a salt protocol (detailed in supplementary material). To 
check the general quality of DNA extracts, we used a subset of 90 randomly chosen individuals to amplify 24 Jaera albifrons microsatellites (Ribardière et al., 2015). In addition, a DNA extract from Oniscus asellus (common woodlouse) known to be infected by Wolbachia was used as positive control to check if Wolbachia was correctly detected by the different methods described below. Three different loci were targeted to increase our detection ability and confidence (details in Table 2). First, we used the wsp gene (Wolbachia surface protein), which encodes a major cell surface coat protein and is one of the most common targets for Wolbachia PCR detection (Braig et al., 1998; Zhou et al., 1998). We used four distinct wsp protocols (wsp-1, wsp-2, wsp-L, and wsp-J, Table 2) with three different pairs of primers, including newly developed primers JwspF 5' CGTTCGTTTACAATACAACGGTGA 3' and JwspR 5' AACCGAAGTAACGAGCTCCA 3'. These new primers were designed from a Wolbachia sequence that we obtained in this study from two individuals of the Jaera albifrons complex (see results). Second, the ribosomal 16S-2 marker was also chosen because it is a universal barcoding locus for bacteria identification that is expected to produce a strong signal (Simoes et al., 2011). Finally, we also used the fbpA primers that amplify a region of the fructose-bisphosphate aldolase gene (Baldo et al., 2006). This method lacks specificity but it can be more sensitive (Simoes et al., 2011). Polymerase Chain Reaction (PCR) conditions are detailed in Tables S3 and S4. PCR products were electrophoresed in 1.5\% agarose gels stained with ethidium bromide and visualized under UV light. Some individuals were tested several times with different primers, bringing the total number of tests to 1692 (or 2445 when including individuals tested several times with the same protocol). A re-amplification based on a subset of PCR products for the wsp gene was also performed for 423 samples to enhance detection ability. Details of analysed samples (primers used, species, sex, origin) are given in supplementary materials (Table S1). The large majority of these tests produced no amplified products (see results), but all amplifications resulting in a single band around the expected size were directly sequenced. Overall, 98 PCR products (in addition to the positive control) were sent for sequencing to Eurofins Genomics (Ebersberg, Germany). The sequences obtained were assembled and checked with the CodonCode 
Aligner software (CodonCode corporation, Centerville, MA) and then compared to the GenBank Nucleotide database using BLAST (Basic Local Alignment Search Tool, NCBI).

To determine the phylogenetic position of the Jaera-specific Wolbachia sequence that we found in this study (see results), we built a neighbour-joining phylogeny using a sample of related sequences deposited in GenBank (with a particular focus on strains found in marine crustaceans, Cordaux et al., 2012).

\section{RESULTS}

\subsection{Adult sex ratio in natural populations}

Between 64 and 115 adult individuals were sampled in each of the four populations chosen for sex ratio estimates. Three out of the four European species of the Jaera albifrons group presented a female-biased sex ratio (Table 1 and Figure 1), with J. ischiosetosa showing the strongest bias (20 males, 94 females, binomial test $p$-value $<0.001)$. J. albifrons and J. forsmani were also characterized by a significant excess of females, while J. praehirsuta did not reveal any bias ( 30 males, 34 females, $p=0.71)$. All males sampled in a site/habitat combination belonged to a single species, except for three J. praehirsuta males that were found in the J. albifrons sample (that is, under rocks), in agreement with the level of habitat overlap between these two species in the region sampled (Ribardière et al., 2017). These males were removed from all analyses but there is a small possibility that some of the females used to estimate the J. albifrons sex ratio were in fact J. praehirsuta (see discussion).

\subsection{Sex ratio in broods reared in the laboratory.}

Using 132 broods from four species that were originally sampled in the French region Brittany (i.e. where species are reproductively isolated), we raised 1349 progenies (Table 4). The average survival rate in the laboratory (that is, from birth to the date when each individual was sexed) was 77.5\%, meaning that 1046 individuals could be sexed successfully across the four species. We 
observed a strong bias towards females in J. ischiosetosa $(r=0.29$, binomial test $p$-value $<0.001)$. The other three species did not show any significant sex bias (Table 3 and Figure 1). The distribution of sex ratio per brood is shown in supplementary material Figure $\mathbf{S}$.

In the case of J. ischiosetosa, we raised 130 offspring from 12 broods with a survival rate of $85 \%$. With 20 dead out of 130 individuals, sex-biased mortality cannot account for the sex ratio bias that we observed. Even if all dead individuals were males, then the sex ratio at birth would still be significantly biased ( 52 theoretical males, 78 females, binomial test $p$-value $=0.028$ ). The same reasoning applies to all four species and we consider laboratory sex ratio as a good proxy for sex ratio at birth (Figure 1).

\subsection{Sex ratio in case of introgressive hybridization between J. albifrons and J. praehirsuta}

First, we compared the sex ratio in broods produced by females J. albifrons and J. praehirsuta in Brittany (no hybridization) and Normandy (introgressive hybridization). For this analysis we had the sex of 798 individuals (out of 1070 offspring isolated) and found no significant bias in sex ratio within each species in each region (all binomial test $p$-values $>0.05$ ) and no significant differences across species and regions (GLM $p$-values $>0.05$ for both factors and their interaction). These results are shown in supplementary material Figure S3.

We came to the same conclusion when analysing broods from experimental crosses featuring J. albifrons, J. praehirsuta, F1 hybrids, and backcross hybrids (Figure 2, 1902 sexed individuals out of 2744 reared offspring). Again we found no significant deviation from even sex ratio within each class

(all binomial test $p$-values $>0.05$ ) and no significant difference between classes (GLM $p$-value $>0.05$ ).

\subsection{PCR detection of Wolbachia}

We searched for Wolbachia in the Jaera albifrons complex by conducting 2,445 tests involving 817 individuals (see supplementary material, Table S1). Overall, 731 individuals were tested more than once, among which 232 have been tested with at least 2 different protocols. None of our 
negative controls showed amplification signals, whilst our positive control (DNA extract from a Wolbachia-infected woodlouse) was correctly and constantly amplified by all methods. Our Jaera microsatellite markers amplified well, suggesting that there was no obvious problem with the general quality of the DNA extraction protocols (linked e.g. with PCR inhibitors).

With the fbpA and 16S-2 protocols no amplification of expected size was detected for any of the tested individuals ( $n=47$ individuals tested for each marker). The wsp- 1 and wsp- 2 protocols produced a weak amplification signal for $6 \%$ ( $n=6$ out of 95 ) and $3 \%$ ( $n=8$ out of 252 ) of the tested individuals, respectively. Re-amplification attempts for 272 of these PCR products (details in Table S1) did not produce any amplicon corresponding to a Wolbachia sequence. By contrast, the sequence obtained with our positive control hit the expected Wolbachia sequence (accession number

\section{AJ276601.1).}

The more sensitive wsp-L protocol, tested on 615 individuals, produced 62 PCR products showing a single band with amplification size close to that expected. These 62 PCR products were directly sequenced, and two of them were identical and showed $>99 \%$ identity with the top Wolbachia wsp hit in Genbank (3 differences out of 540 nucleotides). We deposited this new Wolbachia sequence in Genbank with accession number MH121068. Here again, re-amplification attempts of 102 individuals did not lead to the discovery of further Wolbachia hosts.

The new primers specifically designed from the Wolbachia sequence that we isolated as described above were used with 129 individuals (protocol wsp-J). None of them produced amplification signals (including the two individuals that were previously found to be infected with Wolbachia). Re-amplification of a subset of 40 PCR products did not yield any additional result.

Finally, we used the newly designed primers to re-amplify 53 PCR products previously amplified with the wsp-L primers (chosen because they produced a signal of expected size). Twelve of these re-amplifications produced a strong band at the expected size, and eight of them appeared to be Wolbachia sequences, including the 2 individuals previously detected as positives. All eight individuals shared the same Wolbachia sequence (accession number MH121068). They were all 
females: 1 supposed J. praehirsuta (because found on seaweeds in region Brittany, Ribardière et al., 2017), and 4 J. albifrons, 2 J. praehirsuta and 1 female of unknown species from French region Normandy.

The phylogeny that we built using closely related sequences indicated that our discovered Wolbachia strain belongs to the Rug group of Wolbachia, within the B supergroup (Figure 3, Cordaux et al., 2001). Interestingly, the Rug group happens to be the main Wolbachia group known to include strains infecting marine arthropods (Cordaux et al., 2012).

Finally, the presence of Wolbachia was not detected in any of the other isopod and amphipod species that were tested in this study (Table 3).

\section{DISCUSSION}

Unexpectedly, the four European species of the Jaera albifrons complex followed one of three distinct sex ratio regimes. Two species (J. albifrons and J. forsmani) were found to have balanced sex ratios at birth (as deduced from the sex ratio in young adults and low mortality in laboratory conditions), but a female-biased adult sex ratio in natural populations (Table 1 and Figure 1). This result confirms previous findings for these two species (Cléret, 1966b; Piertney and Carvalho, 1996). More surprising results came from J. ischiosetosa, which showed a strong bias towards females both at the offspring and adult stages, and J. praehirsuta, which showed no bias at any stage (Table 1 and Figure 1).

The case of $J$. ischiosetosa is the most interesting, as it indicates that there is a mechanism in this species that drives a female-biased sex ratio very early in the life cycle. Moreover, this result disagrees with the only other report of sex ratio at birth in this species (Cléret, 1966b), suggesting that there is variation in the sex ratio at birth between populations, or through time (see also Solignac, 1978, p. 89). This points towards endogenous factors such as mitochondrial variants, meiotic drive sex ratio distorters, or reproductive parasites. Here we have performed an intensive survey for the presence of Wolbachia endosymbionts, which were an obvious candidate for 
reproductive manipulation in isopods showing an excess of females. We did not find any trace of Wolbachia in $77 \mathrm{~J}$. ischiosetosa individuals using several different protocols that targeted the wsp region (Table S1). This targeted assay involved the mothers of seven of the 12 broods that were analysed for that species (brood sex ratio from 0.08 to 0.43 , Figures 1 and S2). We conclude from these observations that Wolbachia is either absent or has a low prevalence in J. ischiosetosa and thus cannot be accountable for the excess of females observed in this species.

Other endosymbiotic manipulators of sex (such as bacteria from groups Cardinium, Rickettsia, and Spiroplasma, or microsporidia) could be involved. In their microbiome study, (Wenzel et al., 2018) found evidence for the presence of Rickettsiacea in J. ischiosetosa females (and not in males), but in minute quantities ( $1.16 \%$ of the 16 s sequences obtained for a sample of $J$. ischiosetosa females, M. Wenzel pers. comm.). The best way to test for this hypothesis will be to estimate sex ratio in broods reared in laboratory with and without broad-spectrum antibiotic treatment (Bordenstein et al., 2001; Breeuwer and Jacobs, 1996). Alternatively, the hypothesis of sex ratio distorters borne on the sex chromosomes could be tested using controlled crossing experiments. Finally, although it seems an unlikely hypothesis (ruled out in species J. albifrons, Piertney and Carvalho, 1996), an effect of the environment on sex determination could be further checked specifically in species J. ischiosetosa.

The three other species analysed here did not show any bias in sex ratio at birth, but two of them (J. albifrons and J. forsmani) had female-biased sex ratios at the adult stage in natural populations, in agreement with all previous sex ratio reports for these two species. Hence for these two species at least, males must have lower survival than females in nature. This sex-linked difference in survival is not seen in the laboratory (Piertney and Carvalho, 1996; Solignac, 1978, p. 89), which suggests that it depends on environmental conditions encountered in natural settings. Excluding environmental effects on sex determination (Piertney and Carvalho, 1996), the earlier mortality of males could be due to a difference in costly activities between males and females. In particular, one can imagine that males wander more than females to search for potential mates. 
Moving from one shelter to another could be a risky business in species that live under pebbles and stones on coarse sand or gravel. This sex-specific behaviour could also be linked to a more general pattern of male-biased dispersal. In both cases, it could result in a higher mortality of males seen in nature but not in the laboratory. Mortality risks associated with sex-specific behaviours such as mate seeking or dispersal have been found to impact adult sex ratios in other animal groups (e.g. reviewed in Donald, 2007; Székely et al., 2014).

Interestingly, J. ischiosetosa not only showed a female bias at birth but it was also the species with the strongest bias in adults from natural populations in this study (Table 1 and Figure 1 ) and other works (e.g. Jones and Naylor, 1971). Here we found that the bias in adults ( $r=0.18)$ was significantly stronger than in offspring reared in the laboratory $(r=0.29$, binomial proportions test $p=0.03$ ), suggesting that the factor that causes the female bias at the adult stage in other species may also be acting in J. ischiosetosa.

Finally, the fourth species studied here (J. praehirsuta) did not show any bias at the offspring and adult stages (Table 1 and Figure 1). The most obvious difference between this species and others is that it lives essentially on seaweeds (in our study area). It is thus possible that the male-biased mortality discussed above is habitat-dependent. Since ecological conditions vary widely across the distribution of all species of the Jaera albifrons complex, one straightforward way to test this hypothesis is to compare sex ratios in populations in different ecological contexts (especially different substrate types where one can hypothesize that exploratory movements are more or less facilitated). For instance, while J. praehirsuta is dwelling on seaweeds in our study area (French region Brittany), it is found under pebbles in other areas such as region Normandy. There, this species is found mixed with J. albifrons, with which it hybridizes (Ribardière et al., 2017), making it more difficult to estimate specific sex ratios in nature (also because females cannot be identified unless they are kept in the laboratory until they produce offspring and these offspring are reared for long enough that the males can be identified based on their secondary sexual traits). Nonetheless, the available data for such mixed populations occupying stones and pebbles strongly suggest that the 
sex ratio is female-biased in J. praehirsuta (e.g. 61 males for 138 females of a mixed J. albifrons/J.

praehirsuta population, Ribardière et al. 2017, and the same type of observation was made in populations from the UK where there seems to be no hybridization, M. Wenzel pers. comm.). Hence it seems that the adult female excess is dependent upon ecological conditions, at least in species $J$. praehirsuta.

Our Wolbachia survey involved a large number of individuals $(n=817)$ from the five species of the Jaera albifrons complex sampled in different geographic regions and tested with a variety of protocols ( 11 protocols involving 5 different primer pairs). This effort led to the discovery of a new Wolbachia strain (wsp sequence deposited in Genbank under accession number MH121068) that was detected in J. albifrons and J. praehirsuta. This adds these two species to the limited list of marine crustaceans known to be infected by Wolbachia (Bouchon et al., 1998; Cordaux et al., 2012). Our negative controls always came back negative, no Wolbachia gene amplification was carried in our laboratory before this study, and the new sequence that we found was different from that of our positive control and related to other known marine arthropod-infecting strains. Yet this result must be considered with caution, as this new Wolbachia sequence was amplified from only eight DNA extracts, nearly only using a double amplification protocol (wsp-L followed by wsp-J, see Tables 2 and S1), and could not be replicated using simple-amplification protocols (even using newly designed primers). We conclude that Wolbachia bacteria are present in at least two species of the Jaera albifrons complex in French regions Brittany and Normandy, but most likely with a very small prevalence (both in terms of the number of individuals infected and the concentration of bacteria within infected individuals). This finding consolidates the simultaneous result obtained by Wenzel et al. (2018), where bacterial 16s rDNA sequencing did not reveal any trace of Wolbachia in Scottish populations from the four European species of the Jaera albifrons complex.

Taken together, our observations that i) Wolbachia was not found in the only population showing a female-biased sex ratio at birth (J. ischiosetosa), ii) it was detected in very few individuals in other species, and iii) a single strain was detected in species J. albifrons and J. praehirsuta based 
459 on the wsp locus (and in regions with and without hybridization) lead to the conclusion that

460 Wolbachia bacteria most likely have no feminization or male killing effects in the Jaera albifrons

461 complex, and that they have also no bearing upon reproductive isolation between species within the complex. Sex ratio analyses prompted us to hypothesize that some other sex ratio distorter is acting

463 in a subset of populations (such as the J. ischiosetosa population studied here, and perhaps the J.

464 praehirsuta population reported by Cléret 1966b), and that the ubiquitous excess of adult females in 465 nature may be due to substrate-dependent male-biased mortality. 
466

467

468

469

470

471

472

473

474

475

476

\section{Author contributions}

478 Conceptualization and methodology: AR, CD-T, RC, and TB. Sex ratio data acquisition: AR, JC, JeC, CH, 479

480

481

482

483

\section{Acknowledgements}

We thank Marius Wenzel for sharing ideas and submitted or unpublished results. We thank Elsa Pabion for her help with the maintenance of animals in the laboratory, and Olivier Timsit and Caroline Broudin for helping us collecting individuals in the field. This work benefited from access to the Biogenouest genomic platform at Station Biologique de Roscoff and was supported by the French Agence Nationale de la Recherche (grant ANR-13-JSV7-0001-01 to TB).

\section{Research data}

All data used for the brood sex ratio analyses presented in this article will be available on Dryad upon acceptance

EK, SJ and TB. Molecular investigations: AR, JC, AD, and CD-T. Data curation: AR, JC, and TB. Writing original draft: AR, CD-T and TB. Writing - review and editing: AR, CD-T, RC, and TB. Supervision, project administration and funding acquisition: TB. All authors have approved the final article.

\section{Declarations of interest: none}




\section{References}

Baldo, L., Hotopp, J.C.D., Jolley, K.A., Bordenstein, S.R., Biber, S.A., Choudhury, R.R., Hayashi, C., Maiden, M.C.J., Tettelin, H., Werren, J.H., 2006. Multilocus sequence typing system for the endosymbiont Wolbachia pipientis. Appl Environ Microb 72, 7098-7110.

Bocquet, C., 1953. Recherches sur le polymorphisme naturel des Jaera Marina (Fabr.)(Isopodes Asellotes) : Essai de systématique évolutive. Centre national de la recherche scientifique. Bocquet, C., 1972. La speciation des Jaera albifrons. Etat présent des connaissances et des problèmes. Fifth European Marine Biology Symposium, 131-137.

Bordenstein, S.R., O'Hara, F.P., Werren, J.H., 2001. Wolbachia-induced incompatibility precedes other hybrid incompatibilities in Nasonia. Nature 409, 707-710.

Bordenstein, S.R., Werren, J.H., 1998. Effects of A and B Wolbachia and host genotype on interspecies cytoplasmic incompatibility in Nasonia. Genetics 148, 1833-1844.

Bordenstein, S.R., Werren, J.H., 2007. Bidirectional incompatibility among divergent Wolbachia and incompatibility level differences among closely related Wolbachia in Nasonia. Heredity 99, 278-287. Bouchon, D., Cordaux, R., Grève, P., 2008. Feminizing Wolbachia and the evolution of sex determination in isopods. Insect symbiosis 3, 273-294.

Bouchon, D., Rigaud, T., Juchault, P., 1998. Evidence for widespread Wolbachia infection in isopod crustaceans: molecular identification and host feminization. Proceedings. Biological sciences / The Royal Society 265, 1081-1090.

Braig, H.R., Zhou, W., Dobson, S.L., O'Neill, S.L., 1998. Cloning and Characterization of a Gene Encoding the Major Surface Protein of the Bacterial EndosymbiontWolbachia pipientis. Journal of bacteriology $180,2373-2378$.

Breeuwer, J., Jacobs, G., 1996. Wolbachia: intracellular manipulators of mite reproduction.

Experimental and Applied Acarology 20, 421-434.

Cléret, J.-J., 1966a. Etude d'un facteur polygynique chez Jaera albifrons Leach. (Crustacea, Isopoda). Bull. Soc. lin. Normandie 7, 161-169. 
Cléret, J.-J., 1966b. Le rapport numérique des sexes dans quelques populations naturelles de Jaera albirons Leach. Bull. Soc. lin. Normandie 7, 155-161.

Cordaux, R., Bouchon, D., Greve, P., 2011. The impact of endosymbionts on the evolution of host sexdetermination mechanisms. Trends in Genetics 27, 332-341.

Cordaux, R., Gilbert, C., 2017. Evolutionary Significance of Wolbachia-to-Animal Horizontal Gene Transfer: Female Sex Determination and the f Element in the Isopod Armadillidium vulgare. GenesBasel 8.

Cordaux, R., Michel-Salzat, A., Bouchon, D., 2001. Wolbachia infection in crustaceans: novel hosts and potential routes for horizontal transmission. Journal of evolutionary biology 14, 237-243. Cordaux, R., Pichon, S., Hatira, H.B., Doublet, V., Greve, P., Marcade, I., Braquart-Varnier, C., SoutyGrosset, C., Charfi-Cheilchrouha, F., Bouchon, D., 2012. Widespread Wolbachia infection in terrestrial isopods and other crustaceans. Zookeys, 123-131.

Donald, P.F., 2007. Adult sex ratios in wild bird populations. Ibis 149, 671-692.

Duron, O., Bouchon, D., Boutin, S., Bellamy, L., Zhou, L., Engelstädter, J., Hurst, G.D., 2008. The diversity of reproductive parasites among arthropods: Wolbachia do not walk alone. BMC biology 6, 27.

Duron, O., Hurst, G.D., 2013. Arthropods and inherited bacteria: from counting the symbionts to understanding how symbionts count. BMC biology 11,45 .

Fisher, R.A., 1999. The genetical theory of natural selection: a complete variorum edition. Oxford University Press.

Hardy, I.C., 2002. Sex ratios, Concepts and research methods. Cambridge University Press, UK. Hurst, G.D., Jiggins, F.M., von der Schulenburg, J.H.G., Bertrand, D., West, S.A., Goriacheva, I.I., Zakharov, I.A., Werren, J.H., Stouthamer, R., Majerus, M.E., 1999. Male-killing Wolbachia in two species of insect. Proceedings of the Royal Society of London B: Biological Sciences 266, 735-740. Jaenike, J., 2001. Sex chromosome meiotic drive. Annual Review of Ecology and Systematics 32, 2549. 
Jaenike, J., Dyer, K.A., Cornish, C., Minhas, M.S., 2006. Asymmetrical reinforcement and Wolbachia infection in Drosophila. PLoS Biol 4, e325.

Jaźdźewski, K., 1969. Ecology and Biology of Species of the j aEra Albifrons Group (Isopoda Asellota) in the Bay of Puck, Polish Baltic Sea. Crustaceana 17, 265-281.

Jeyaprakash, A., Hoy, M.A., 2000. Long PCR improves Wolbachia DNA amplification: wsp sequences found in 76\% of sixty-three arthropod species. Insect Mol Biol 9, 393-405.

Jones, M., 1972. Effects of salinity on the survival of the Jaera albifrons Leach group of species (Crustacea: Isopoda). Journal of Experimental Marine Biology and Ecology 9, 231-237. Jones, M.B., Naylor, E., 1971. Breeding and bionomics of the British members of the Jaera albifrons group of species (Isopoda: Asellota). Journal of Zoology 165, 183-199.

Lécher, P., 1967. Cytogénétique de l'hybridation expérimentale et naturelle chez l'isopode Jaera (albifrons) syei Bocquet. Archives de zoologie expérimentale et générale 108, 633-698.

Lécher, P., Prunus, G., 1971. Caryologie et taxinomie de Jaera albifrons (crustacé, isopode), populations des côtes Bretonnes. Archives de Zoologie expérimentale et générale 112, 715-730. Mifsud, D.V., 2011. The genetic basis of speciation in the Jaera albifrons species group of intertidal isopods. University of Aberdeen, p. 201.

Naylor, E., Haahtela, I., 1966. Habitat Preferences and Interspersion of Species within Superspecies Jaera Albifrons Leach (Crustacea . Isopoda). Journal of Animal Ecology 35, 209-\&.

Naylor, E., Haahtela, I., 1967. Quantitative ecological distribution of the Jaera albifrons group of species in the Baltic. Ophelia 4, 19-27.

Naylor, E., Slinn, D., Spooner, G., 1961. Observations on the British species of Jaera (Isopoda: Asellota). Journal of the Marine Biological Association of the United Kingdom 41, 817-828. Piertney, S.B., Carvalho, G.R., 1996. Sex ratio variation in the intertidal isopod, Jaera albifrons. Journal of the Marine Biological Association of the United Kingdom 76, 825-828.

Policansky, D., 1982. Sex change in plants and animals. Annual Review of Ecology and Systematics 13, 471-495. 
Poore, C.B., Bruce, N.L., 2012. Global diversity of marine isopods (except Asellota and Crustacean symbionts). PLoS One 7.

R Core Team, 2016. R: A language and environment for statistical computing. R Foundation for Statistical Computing, Vienna, Austria.

Ribardière, A., 2017. Isolement reproductif et architecture génomique de la différenciation chez deux espèces du complexe Jaera albifrons (isopodes marins) - Etude de populations mixtes présentant des niveaux d'isolement interspécifique contrastés. Phd Thesis, UPMC.

Ribardière, A., Broquet, T., Daguin-Thiebaut, C., 2015. Microsatellite markers for the Jaera albifrons species complex (marine isopods). BMC research notes 8, 632 .

Ribardière, A., Daguin-Thiébaut, C., Houbin, C., Coudret, J., Broudin, C., Timsit, O., Broquet, T., 2017. Geographically distinct patterns of reproductive isolation and hybridization in two sympatric species of the Jaera albifrons complex (marine isopods). Ecology and evolution.

Rigaud, T., Moreau, J., Juchault, P., 1999. Wolbachia infection in the terrestrial isopod Oniscus asellus: sex ratio distortion and effect on fecundity. Heredity 83, 469-475.

Rousset, F., Bouchon, D., Pintureau, B., Juchault, P., Solignac, M., 1992. Wolbachiae ndosymbionts responsible for various alterations of sexuality in arthropods. Proceedings of the Royal Society of London B 250, 91-98.

Sazama, E.J., Bosch, M.J., Shouldis, C.S., Ouellette, S.P., Wesner, J.S., 2017. Incidence of Wolbachia in aquatic insects. Ecology and evolution 7, 1165-1169.

Simoes, P.M., Mialdea, G., Reiss, D., Sagot, M.F., Charlat, S., 2011. Wolbachia detection: an assessment of standard PCR protocols. Molecular ecology resources 11, 567-572.

Solignac, M., 1969a. Contiguous distributions sympatry and natural hybridization in a super-species Jaera albifrons Leach (isopods asellidae). Comptes Rendus Hebdomadaires des Séances de I'Academie des Sciences SERIE D 268, 1610-\&.

Solignac, M., 1969b. Hybridation introgressive dans la population complexe des Jaera albifrons de Luc sur Mer. Arch Zool Exp Gén 110, 629-652. 
Solignac, M., 1976. Demographic Aspects of Interspecific Hybridization. Oecologia 26, 33-52.

Solignac, M., 1978. Nature, déterminisme et origine des mécanismes d'isolement dans le complexe Jaera albifrons (Isopodes, Asellotes). Phd Thesis. Paris 6, p. 232.

Solignac, M., 1979. Analyse expérimentale et variabilité de l'hybridation interspécifique dans le complexe d'espèces affines Jaera albifrons (crustacé isopode). Archives de zoologie expérimentale et générale 120, 353.

Solignac, M., 1981. Isolating mechanisms and modalities of speciation in the Jaera albifrons species complex (Crustacea, Isopoda). Systematic Zoology 30, 387-405.

Staiger, H., Bocquet, C., 1954. Cytological demonstration of female heterogamety in isopods. Experientia 10, 64-66.

Staiger, H., Bocquet, C., 1956. Les chromosomes de la super-espèce Jaera marina (F.) et de quelques autres Janiridae (Isopodes Asellotes). Bull. Biol. Fr. Belg 90, 1-32.

Steele, D., Steele, V., 1972. The biology of Jaera spp.(Crustacea, Isopoda) in the northwestern Atlantic. 1. Jaera ischiosetosa. Canadian Journal of Zoology 50, 205-211.

Székely, T., Weissing, F.J., Komdeur, J., 2014. Adult sex ratio variation: implications for breeding system evolution. Journal of Evolutionary Biology 27, 1500-1512.

Taylor, D.R., 1990. Evolutionary consequences of cytoplasmic sex ratio distorters. Evolutionary Ecology 4, 235-248.

Telschow, A., Flor, M., Kobayashi, Y., Hammerstein, P., Werren, J.H., 2007. Wolbachia-induced unidirectional cytoplasmic incompatibility and speciation: mainland-island model. PloS one 2, e701. Turelli, M., Cooper, B.S., Richardson, K.M., Ginsberg, P.S., Peckenpaugh, B., Antelope, C.X., Kim, K.J., May, M.R., Abrieux, A., Wilson, D.A., 2018. Rapid Global Spread of wRi-like Wolbachia across Multiple Drosophila. Current Biology.

Vavre, F., Fleury, F., Lepetit, D., Fouillet, P., Boulétreau, M., 1999. Phylogenetic evidence for horizontal transmission of Wolbachia in host-parasitoid associations. Molecular biology and evolution 16, 1711-1723. 
614 Wenzel, M.A., Douglas, A., Piertney, S.B., 2018. Microbiome composition within a sympatric species 615 complex of intertidal isopods (Jaera albifrons). PLoS One.

616 Werren, J.H., 1983. Sex ratio evolution under local mate competition in a parasitic wasp. Evolution $617 \quad 37,116-124$.

618 Werren, J.H., 1997. Biology of wolbachia. Annual review of entomology 42, 587-609.

619 Werren, J.H., Baldo, L., Clark, M.E., 2008. Wolbachia: master manipulators of invertebrate biology.

620 Nature Reviews Microbiology 6, 741-751.

621 Werren, J.H., Windsor, D.M., 2000. Wolbachia infection frequencies in insects: evidence of a global

622 equilibrium? Proceedings. Biological sciences / The Royal Society 267, 1277-1285.

623 West, S.A., Sheldon, B.C., 2002. Constraints in the evolution of sex ratio adjustment. Science 295, $624 \quad 1685-1688$.

625 Zhou, W., Rousset, F., O'Neill, S., 1998. Phylogeny and PCR-based classification of Wolbachia strains 626 using wsp gene sequences. Proceedings of the Royal Society of London B: Biological Sciences 265, $627 \quad 509-515$. 


\section{Tables}

Table 1. Number of males and females in natural populations of the four European species of the Jaera albifrons complex. Departure from an even sex ratio (proportion of males) was tested using a binomial test within each site $\left({ }^{*} p<0.05,{ }^{* *} p<0.01,{ }^{* * *} p<0.001\right)$.

\begin{tabular}{|c|c|c|c|c|c|c|}
\hline Species & Site & Habitat & Coordinates & Males & Females & Sex ratio \\
\hline J. albifrons & Lingoz & rocks & $\begin{array}{l}48^{\circ} 39^{\prime} 12.31^{\prime \prime} \mathrm{N} \\
3^{\circ} 57^{\prime} 0.43^{\prime \prime} \mathrm{W}\end{array}$ & 15 & 49 & $0.23 * * *$ \\
\hline J. praehirsuta & Lingoz & algae & $\begin{array}{l}48^{\circ} 39^{\prime} 12.31^{\prime \prime} \mathrm{N} \\
3^{\circ} 57^{\prime} 0.43^{\prime \prime} \mathrm{W}\end{array}$ & 30 & 34 & 0.47 \\
\hline J. ischiosetosa & Pempoul & rocks & $\begin{array}{l}48^{\circ} 41^{\prime} 16.9^{\prime \prime} \mathrm{N} \\
3^{\circ} 57^{\prime} 27.6^{\prime \prime} \mathrm{W}\end{array}$ & 20 & 94 & $0.18^{* * *}$ \\
\hline J. forsmani & Pointe Grande Grève & rocks & $\begin{array}{l}48^{\circ} 42^{\prime} 22.6^{\prime \prime} \mathrm{N} \\
3^{\circ} 58^{\prime} 18.7^{\prime \prime} \mathrm{W}\end{array}$ & 41 & 74 & $0.36^{* *}$ \\
\hline
\end{tabular}


Table 2. Primers used in the six protocols tested in this study. Protocols $W s p-1$ and -2 use the same primers with different PCR conditions (see supplementary Tables S3 and S4).

\begin{tabular}{llcc}
\hline Name & Primer (F/R) & Product size (bp) & Reference \\
\hline Wsp-1 & 81F/691R & 610 & Zhou et al. (1998) \\
Wsp-2 & $81 F / 691 R$ & 650 & Braig et al. (1998) \\
Wsp-L & LongF/LongR & 657 & Jeyaprakash and Hoy (2000) \\
Wsp-J & JwspF/JWspR & 464 & This study \\
$16 S-2$ & Wspecf/Wspcr & 438 & Werren and Windsor (2000) \\
$f b p A$ & FbpA_F1/FbpA_R1 & 509 & Baldo et al. (2006) \\
\hline
\end{tabular}


Table 3. Number of males and females obtained from broods reared in the laboratory for the four European species of the Jaera albifrons complex. Column "sexed" gives the number of individuals that survived and were sexed, out of the total number of offspring isolated at birth ( $n$ ). Departure from an even sex ratio (proportion of males) was tested using a binomial test within each site $\left({ }^{* * *} p<0.001\right)$.

\begin{tabular}{lccccc}
\hline Species & $n$ & sexed & males & females & sex ratio \\
\hline J. albifrons & 655 & 497 & 240 & 257 & 0.48 \\
J. praehirsuta & 211 & 116 & 61 & 55 & 0.53 \\
J. ischiosetosa & 130 & 110 & 32 & 78 & $0.29 * * *$ \\
J. forsmani & 353 & 323 & 171 & 152 & 0.53 \\
\hline
\end{tabular}




\section{Figure legends}

Figure 1: Sex ratio (proportion males) in the four European species of the Jaera albifrons complex. Grey bars indicate $95 \%$ binomial confidence intervals around the observed sex ratio. All species but J. praehirsuta were found to be significantly female-biased at the adult stage in natural populations (sample sizes in tables 1 and 6). Only J. ischiosetosa presented a female-biased sex ratio in young adults reared in the laboratory (a good proxy for the sex ratio at birth when mortality is low, as in this study).

Figure 2: Distribution of offspring sex ratio per brood in Jaera albifrons ( $n=131$ broods), J. praehirsuta ( $n=134$ ), first-generation hybrids ( $n=17)$, and backcross hybrids (first generation female hybrids crossed with either J. albifrons or J. praehirsuta males, $n=58$ ). All broods were obtained from experimental crosses where both the mother and the father were known.

Figure 3: Neighbour joining tree of some Supergroup-B Wolbachia sequences, based on Kimura 2parameters distances. Strains infecting marine hosts are represented in black, and the Wolbachia sequence that we found in J. albifrons and J. praehirsuta is highlighted. Other Wolbachia sequences identified in non-marine hosts are represented in grey. The strain that we used as a positive control is identified with an asterisk. The definition of the "RUG" group follows Cordaux et al. (2012). Bootstrap support inferred from 1000 replicates is shown when it is greater than $50 \%$. 
Figure 1

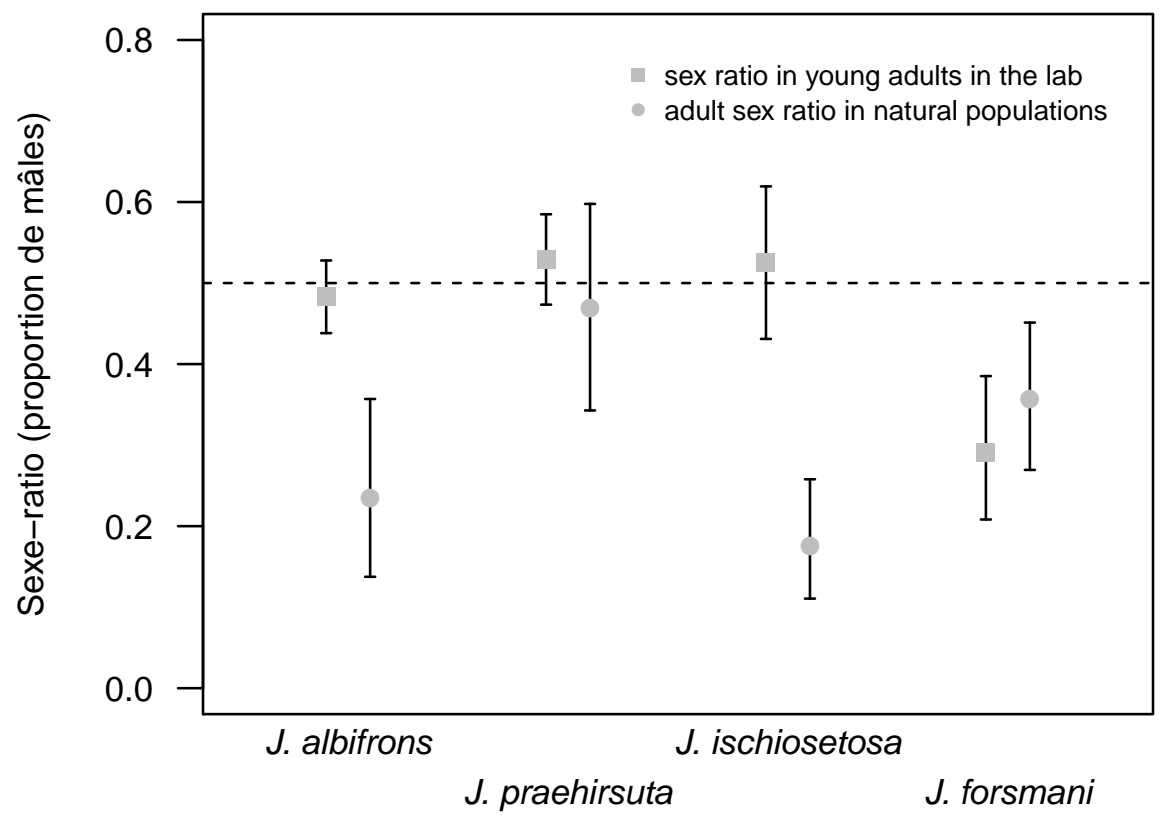


Figure 2

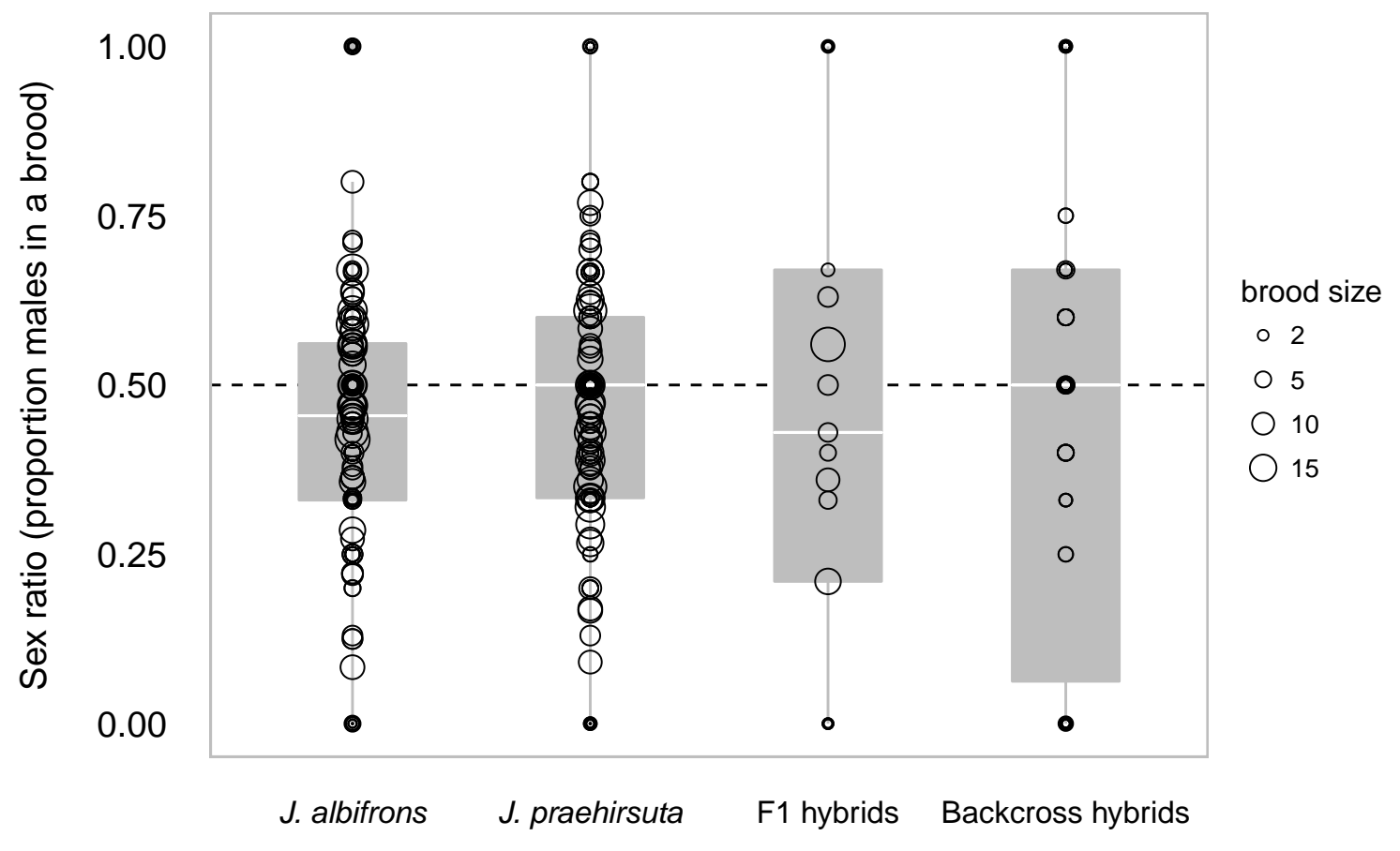


Figure 3

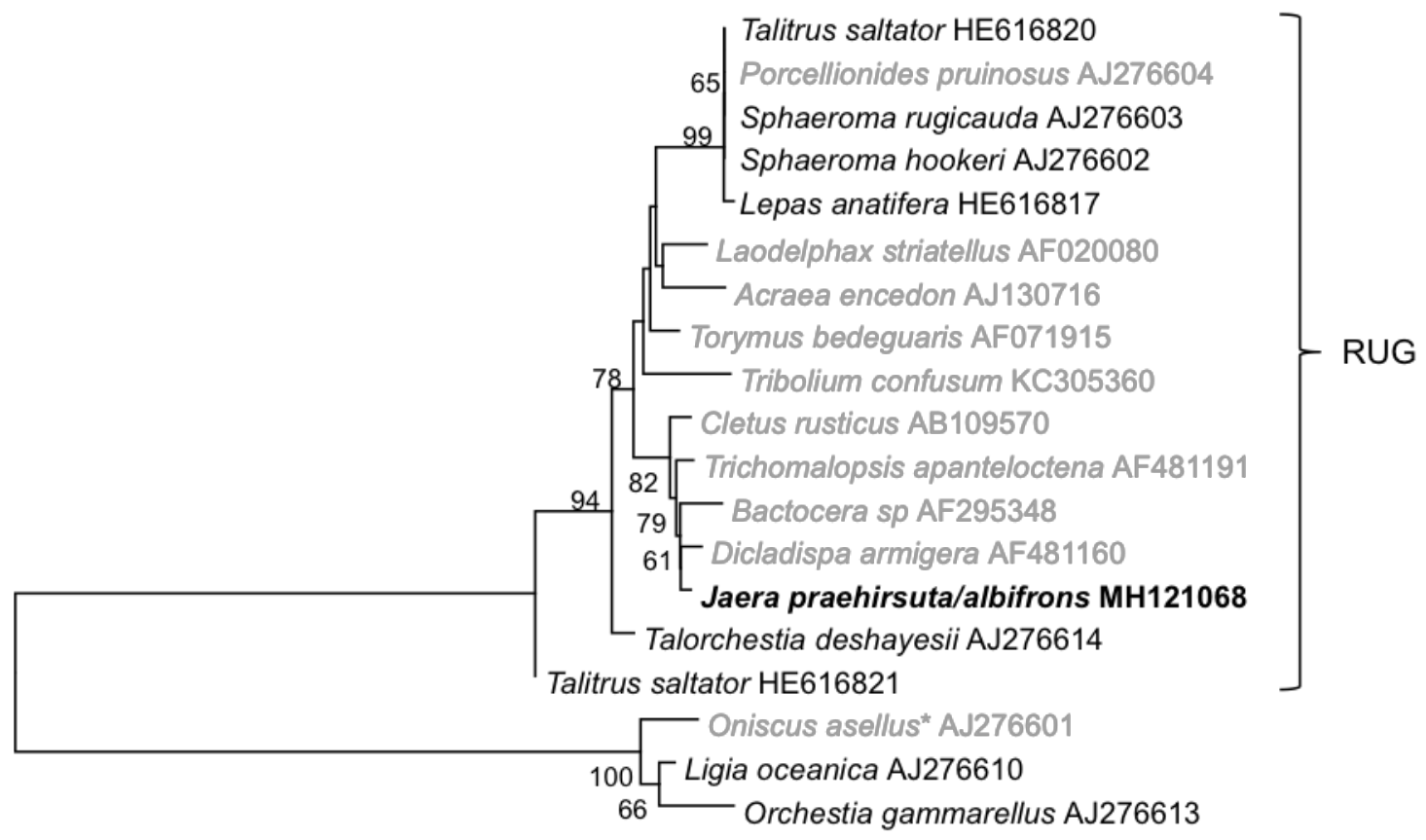

0.02 


\section{Supplementary material}

\section{Rearing conditions}

Lab conditions were as follows. All individuals were reared individually in 6-well plates (one individual per well, each well has a diameter of approximately $3.5 \mathrm{~cm}$ and contains ca. $10 \mathrm{~mL}$ of $3 \mu \mathrm{m}$-filtered seawater). Following the conditions described in Bocquet (Bocquet 1953: 212-213), each well contained small pieces of green algae (Enteromorpha sp.) and a small piece of elm leaf (elm leaves provide shelter and food, and have been used successfully for several decades by previous researchers). The plates were kept in thermostat cabinets at $17^{\circ} \mathrm{C}$ with an $11 \mathrm{~h} / 13 \mathrm{~h}$ light/obscurity cycle and seawater was changed once a week (together with algae and leaves when needed). Embryos develop in a marsupium (brood pouch containing typically around 15 offspring) until the female releases them. At that stage the offspring measure approximately half a millimetre and closely resemble the adults (direct development, no pelagic larval stage). Offspring were isolated one by one within a few days after their release and reared individually in the same conditions as the adults, with two exceptions: seawater was not changed during the first week, and elm leaves were added only during the second week. Under these conditions, individuals can usually be sexed around the age of 4 to 5 weeks but all experiments lasted for a longer time. Since each individual was reared individually (and thus the number of offspring per brood was counted) the survival rate could be estimated for each brood.

\section{Salt extraction protocol}

Entire individuals were mashed then tissues were soaked into $500 \mu \mathrm{l}$ of $\mathrm{NaCl}$ buffer (containing $1 \%$ SDS, $150 \mathrm{mM} \mathrm{NaCl}, 1 \mathrm{mM}$ EDTA and $20 \mathrm{mM}$ TRIS) with $1 \mathrm{mg}$ of proteinase-K (Macherey-Nagel, Duren, Germany) and incubated at $56^{\circ} \mathrm{C}$ during $3 \mathrm{~h} 30$ under agitation at $120 \mathrm{rpm} .0 .5 \mathrm{mg}$ of ribonuclease A (Macherey-Nagel, Duren, Germany) was added to each tube and incubated for 20 min under agitation at room temperature. $200 \mu \mathrm{l}$ of $\mathrm{NaCl}$ buffer (5M) was then added and the tubes were 
centrifuged at 16,000 g for $10 \mathrm{~min}$. Supernatant was pipeted and mix to an equal volume of cold isopropanol and stored overnight at $-20^{\circ} \mathrm{C}$. After centrifugation at $16,000 \mathrm{~g}$ for $15 \mathrm{~min}$, the DNA pellet was washed with $500 \mu \mathrm{l}$ of $80 \%$ cold ethanol and with $70 \%$ cold ethanol subsequently. DNA pellets were then dried and again suspended in $100 \mu \mathrm{l}$ of TE $0.1 \mathrm{X}$. 
Table S1. List of the samples tested with the different protocols

\begin{tabular}{|c|c|c|c|c|c|c|c|c|c|c|c|c|c|c|c|}
\hline location & species & sex & $\begin{array}{c}\text { num. of } \\
\text { indiv. }\end{array}$ & $16 S-2$ & Fbp-A & Wsp-1 & Wsp-2 & Wsp-L & Wsp-J & $\begin{array}{l}\text { Wsp-1 } \\
\text { Wsp-2 }\end{array}$ & $\begin{array}{l}\text { Wsp-2 } \\
\text { Wsp-2 }\end{array}$ & $\begin{array}{l}\text { Wsp-L } \\
\text { Wsp-L }\end{array}$ & $\begin{array}{l}\text { Wsp-J } \\
\text { Wsp-J }\end{array}$ & $\begin{array}{l}\text { Wsp-L } \\
\text { Wsp-J }\end{array}$ & TOTAL \\
\hline \multirow[t]{9}{*}{ France - Brittany (5 sites) } & J. albifrons & $\mathrm{F}$ & 32 & 15 & 2 & 8 & 16 & 25 & 0 & 8 & 1 & 0 & 0 & 0 & 75 \\
\hline & J. albifrons & M & 86 & 6 & 0 & 13 & 5 & 74 & 45 & 13 & 1 & 3 & 0 & 0 & 160 \\
\hline & J. praehirsuta & $\mathrm{F}$ & 25 & 1 & 16 & 8 & 8 & 25 & 9 & 8 & 0 & 4 & 9 & 1 & 89 \\
\hline & J. praehirsuta & M & 55 & 3 & 0 & 9 & 0 & 51 & 26 & 9 & 0 & 9 & 0 & 0 & 107 \\
\hline & J. ischiosetosa & $\mathrm{F}$ & 33 & 0 & 0 & 0 & 6 & 32 & 0 & 0 & 2 & 29 & 0 & 30 & 99 \\
\hline & J. ischiosetosa & $M$ & 39 & 0 & 0 & 3 & 2 & 39 & 8 & 3 & 0 & 28 & 0 & 16 & 99 \\
\hline & J. forsmani & $\mathrm{F}$ & 1 & 0 & 0 & 0 & 1 & 1 & 0 & 0 & 0 & 0 & 0 & 0 & 2 \\
\hline & J. forsmani & $M$ & 15 & 0 & 0 & 8 & 0 & 15 & 8 & 8 & 0 & 3 & 0 & 0 & 42 \\
\hline & NA & $\mathrm{F}$ & 7 & 0 & 0 & 0 & 7 & 0 & 0 & 0 & 7 & 0 & 0 & 0 & 14 \\
\hline \multirow[t]{7}{*}{ France - Normandy (2 sites) } & J. albifrons & $\mathrm{F}$ & 23 & 1 & 0 & 15 & 16 & 17 & 15 & 15 & 0 & 4 & 15 & 4 & 102 \\
\hline & J. albifrons & M & 163 & 3 & 13 & 6 & 0 & 161 & 0 & 6 & 0 & 12 & 0 & 0 & 201 \\
\hline & J. praehirsuta & $\mathrm{F}$ & 20 & 15 & 0 & 1 & 12 & 16 & 16 & 1 & 0 & 2 & 16 & 2 & 81 \\
\hline & J. praehirsuta & M & 79 & 0 & 7 & 11 & 0 & 77 & 0 & 11 & 0 & 2 & 0 & 0 & 108 \\
\hline & $\begin{array}{l}\text { J. albifrons / J. } \\
\text { praehirsuta } \\
\text { inter. morph. }\end{array}$ & M & 23 & 2 & 8 & 0 & 0 & 23 & 0 & 0 & 0 & 1 & 0 & 0 & 34 \\
\hline & J. forsmani & M & 2 & 0 & 1 & 0 & 0 & 2 & 0 & 0 & 0 & 1 & 0 & 0 & 4 \\
\hline & NA & $\mathrm{F}$ & 74 & 1 & 0 & 0 & 73 & 4 & 0 & 0 & 70 & 0 & 0 & 0 & 148 \\
\hline \multirow[t]{3}{*}{ England - Scilly Islands } & J. albifrons & M & 7 & 0 & 0 & 0 & 0 & 7 & 0 & 0 & 0 & 1 & 0 & 0 & 8 \\
\hline & J. praehirsuta & M & 12 & 0 & 0 & 0 & 0 & 12 & 0 & 0 & 0 & 0 & 0 & 0 & 12 \\
\hline & NA & $\mathrm{F}$ & 10 & 0 & 0 & 0 & 8 & 10 & 0 & 0 & 0 & 3 & 0 & 0 & 21 \\
\hline Norway (1 site) & NA & $\mathrm{F}$ & 43 & 0 & 0 & 0 & 43 & 5 & 0 & 0 & 43 & 0 & 0 & 0 & 91 \\
\hline \multirow[t]{4}{*}{ Canada - East coast ( 2 sites) } & J. albifrons & M & 2 & 0 & 0 & 0 & 0 & 2 & 2 & 0 & 0 & 0 & 0 & 0 & 4 \\
\hline & J. ischiosetosa & M & 5 & 0 & 0 & 5 & 2 & 5 & 0 & 5 & 0 & 0 & 0 & 0 & 17 \\
\hline & J. posthirsuta & M & 8 & 0 & 0 & 8 & 0 & 8 & 0 & 8 & 0 & 0 & 0 & 0 & 24 \\
\hline & NA & $\mathrm{F}$ & 53 & 0 & 0 & 0 & 53 & 4 & 0 & 0 & 53 & 0 & 0 & 0 & 110 \\
\hline TOTAL & & & 817 & 47 & 47 & 95 & 252 & 615 & 129 & 95 & 177 & 102 & 40 & 53 & \\
\hline
\end{tabular}


Table S2. Marine isopod and amphipod species tested for Wolbachia

\begin{tabular}{lll}
\hline Species & Order & Number of individuals \\
\hline Jaera hopeana & Isopoda & 8 \\
Jaera nordmanni & Isopoda & 4 \\
Janira maculosa & Isopoda & 5 \\
Sphaeroma serratus & Isopoda & 1 \\
Haploops nirae & Amphipoda & 8 \\
Ampelisca spinipes & Amphipoda & 8 \\
\hline
\end{tabular}


Table S3. PCR mix composition for the six protocols used in this study.

\begin{tabular}{lcccccc}
\hline Name & $\begin{array}{c}\mathrm{MgCl} 2 \\
(\mathrm{mM})\end{array}$ & primers $(\mu \mathrm{M})$ & $\begin{array}{c}\mathrm{dNTPs} \\
(\mathrm{mM})\end{array}$ & Taq $(\mathrm{U})$ & $\begin{array}{c}\text { Template } \\
\text { DNA }(\mu \mathrm{l})\end{array}$ & $\begin{array}{c}\text { Final } \\
\text { Volume }(\mu \mathrm{l})\end{array}$ \\
\hline $16 S-2$ & 1.5 & 0.28 & 0.2 & 1 & 3 & 20 \\
fbpA & 1.5 & 1 & 0.2 & 1 & 3 & 20 \\
Wsp-1 & 2.5 & 0.5 & 0.25 & 1 & 3 & 20 \\
Wsp-2 & 1.5 & $0.28-0.8$ & 0.05 & 0.75 & 2 & 15 \\
Wsp-L & 2 & $0.5-1$ & 0.2 & 1 & 0.6 & 20 \\
Wsp-J & 2 & $0.5-1.33$ & 0.2 & 1 & 0.6 & 20 \\
\hline
\end{tabular}

Table S4. PCR program details; T: Temperature $\left({ }^{\circ} \mathrm{C}\right) ; \mathrm{D}$ : Duration (sec). A touchdown program was used for $16 \mathrm{~S}-2$ (presented on two lines.

\begin{tabular}{|c|c|c|c|c|c|c|c|c|c|c|c|}
\hline \multirow[t]{2}{*}{ Name } & \multicolumn{2}{|c|}{$\begin{array}{c}\text { Initial } \\
\text { denaturation }\end{array}$} & \multicolumn{2}{|c|}{ Denaturation } & \multicolumn{2}{|c|}{ Annealing } & \multicolumn{2}{|c|}{ Elongation } & \multirow[t]{2}{*}{$\begin{array}{l}\text { Nb of } \\
\text { cycles }\end{array}$} & \multicolumn{2}{|c|}{$\begin{array}{c}\text { Final } \\
\text { elongation }\end{array}$} \\
\hline & $T$ & $\mathrm{D}$ & $T$ & $\mathrm{D}$ & $\mathrm{T}$ & $D$ & $T$ & $D$ & & $T$ & $D$ \\
\hline \multirow[t]{2}{*}{$16 S-2$} & 95 & 120 & 95 & 120 & 60 & 60 & 72 & 60 & 2 & NA & NA \\
\hline & & & 95 & 30 & 60 & 60 & 72 & 45 & 35 & 72 & 300 \\
\hline fbpA & 94 & 120 & 94 & 30 & 59 & 45 & 72 & 90 & 36 & 72 & 600 \\
\hline Wsp-1 & 94 & 120 & 94 & 60 & 55 & 60 & 72 & 60 & 35 & 72 & 600 \\
\hline Wsp-2 & 94 & 180 & 94 & 30 & 55 & 30 & 72 & 60 & 35 & 72 & 600 \\
\hline Wsp-L & 98 & 30 & 98 & 15 & 55 & 20 & 72 & 60 & 50 & 72 & 600 \\
\hline Wsp-J & 98 & 30 & 98 & 15 & 54 & 20 & 72 & 60 & 35 & 72 & 600 \\
\hline
\end{tabular}




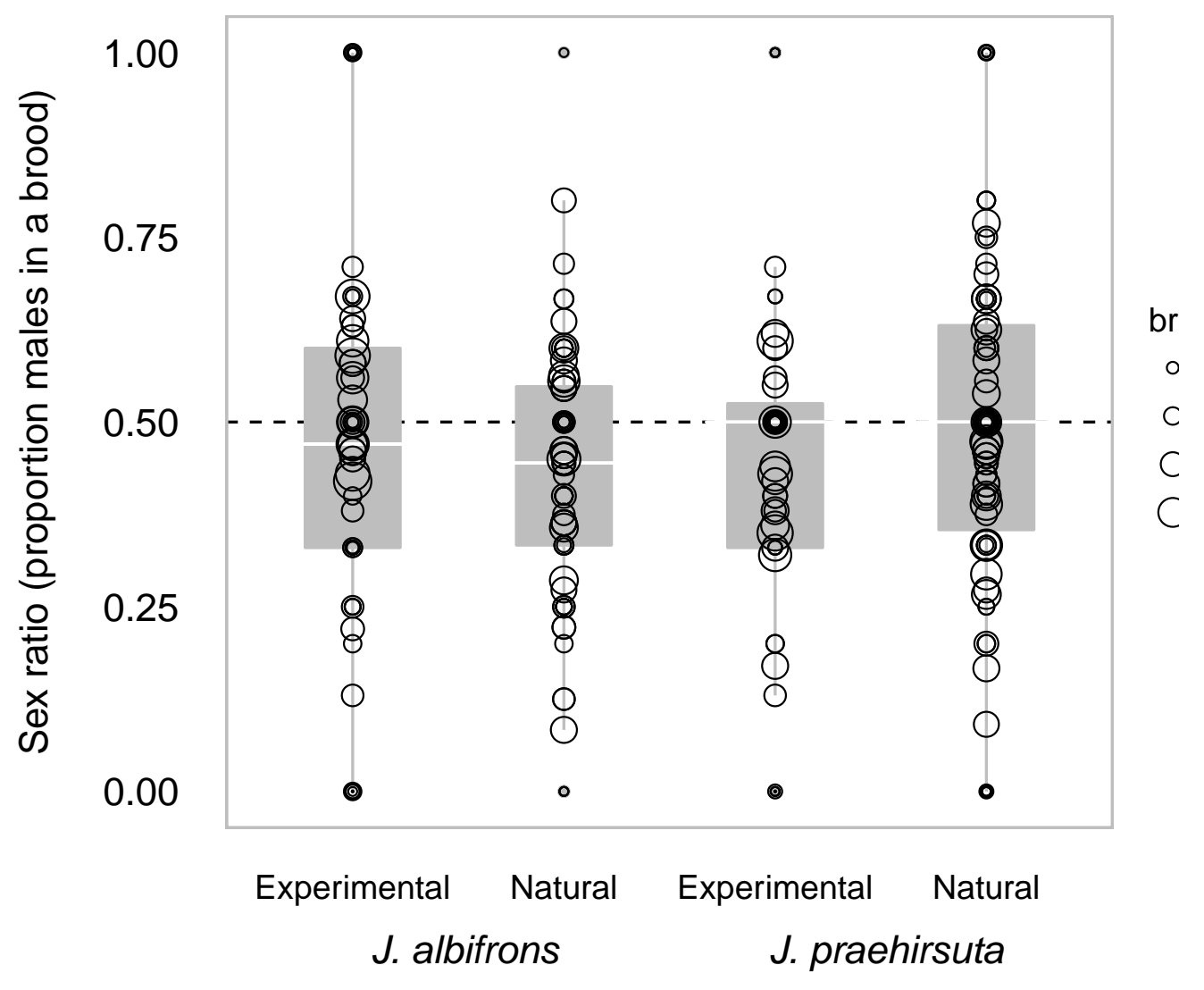

Figure S1. Distribution of offspring sex ratio per brood in Jaera albifrons (59 experimen natural broods) and J. praehirsuta (47 and 87 ). Each brood was reared in the lab until in were sexed, but the brood came either from a female sampled in the wild ("Natural") o female that was itself born and reared in the lab until maturity and used in a controlled experiment ("Experimental"). This figure combines data from the two regions where J. । J. praehirsuta were studied (Brittany and Normandy, see maintext). 


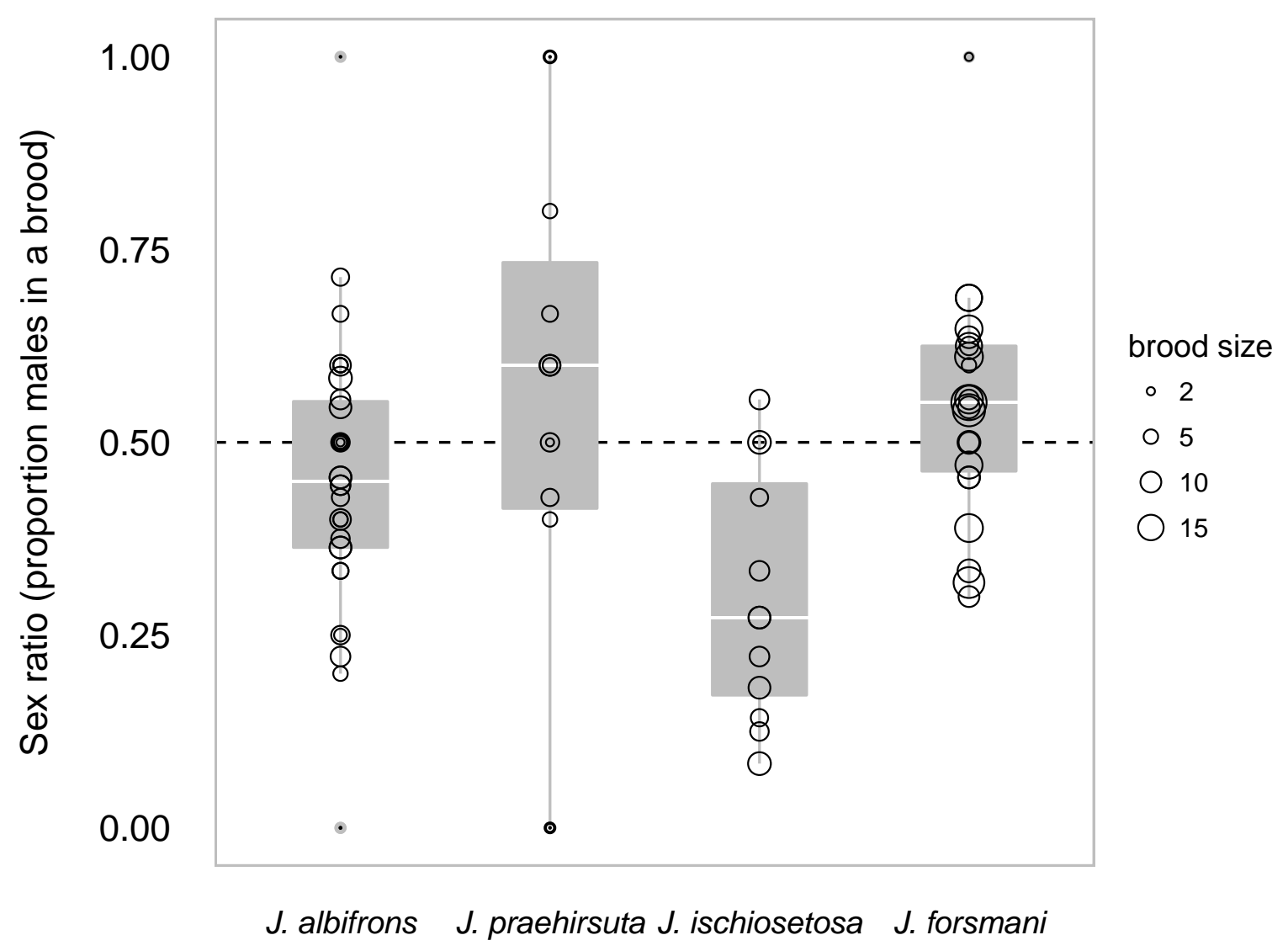

Figure S2. Distribution of offspring sex ratio per brood in Jaera albifrons ( $n=34$ broods), J. praehirsuta $(n=15)$, J. ischiosetosa $(n=12)$, and J. forsmani $(n=23)$. These broods were produced by mothers sampled from natural populations in Brittany (i.e. uncontrolled mating, fathers unknown). The average brood sex ratio in J. ischiosetosa is significantly biased towards females $(r=0.29$, binomial test $p$-value $<0.001)$. 


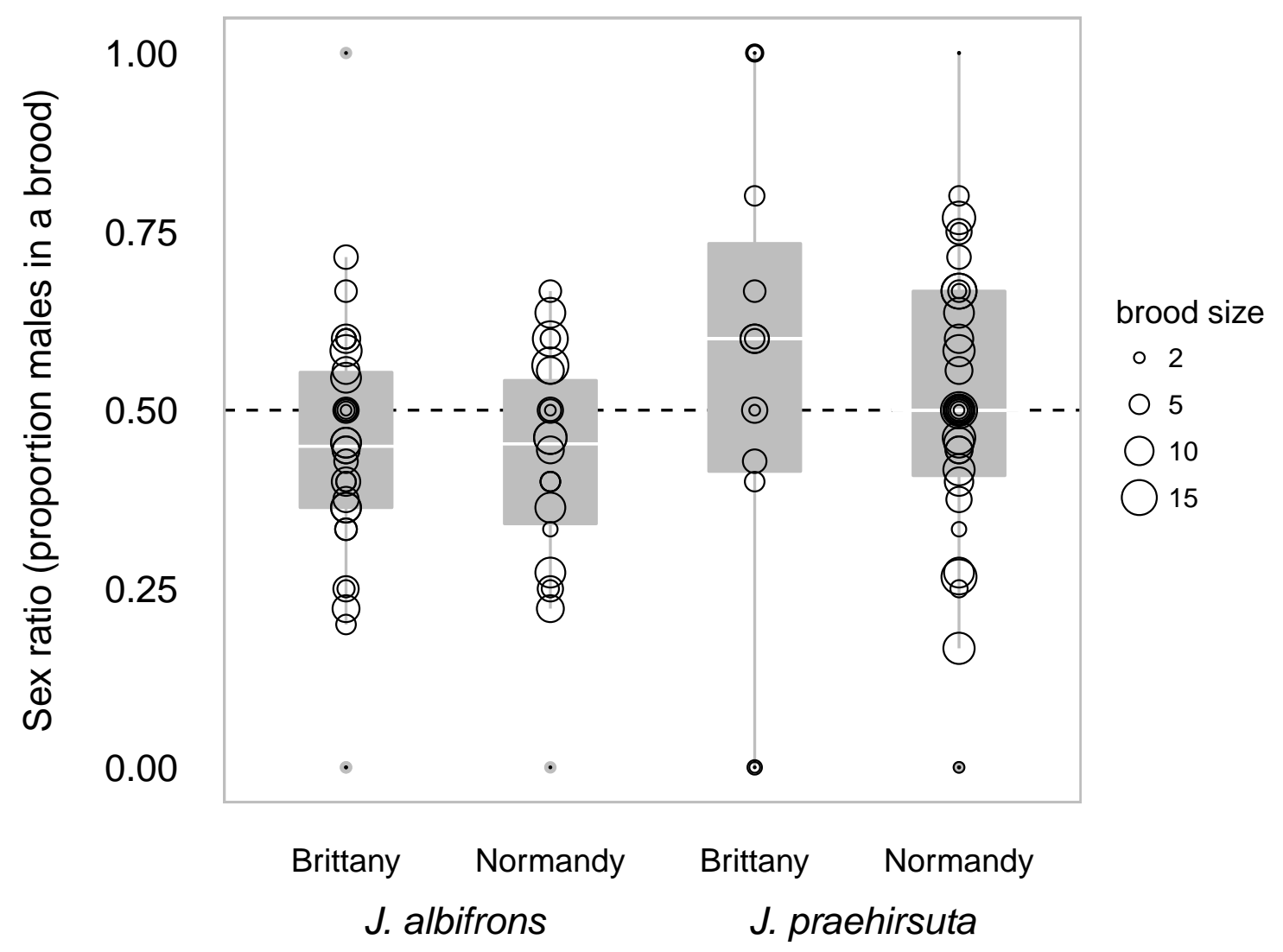

Figure S3. Distribution of offspring sex ratio per brood in Jaera albifrons and J. praehirsuta in a region where the two species are reproductively isolated (Brittany, $n_{\text {albifrons }}=34$ broods, $n_{\text {praehirsuta }}=15$ ) and in a region with introgressive hybridization (Normandy, $n_{\text {albifrons }}=22, n_{\text {praehirsuta }}=39$ ). These broods were produced by mothers sampled from natural populations (i.e. uncontrolled mating, fathers unknown).

\section{References}

Bocquet, C., 1953. Recherches sur le polymorphisme naturel des Jaera Marina (Fabr.)(Isopodes Asellotes) : Essai de systématique évolutive. Centre national de la recherche scientifique. 